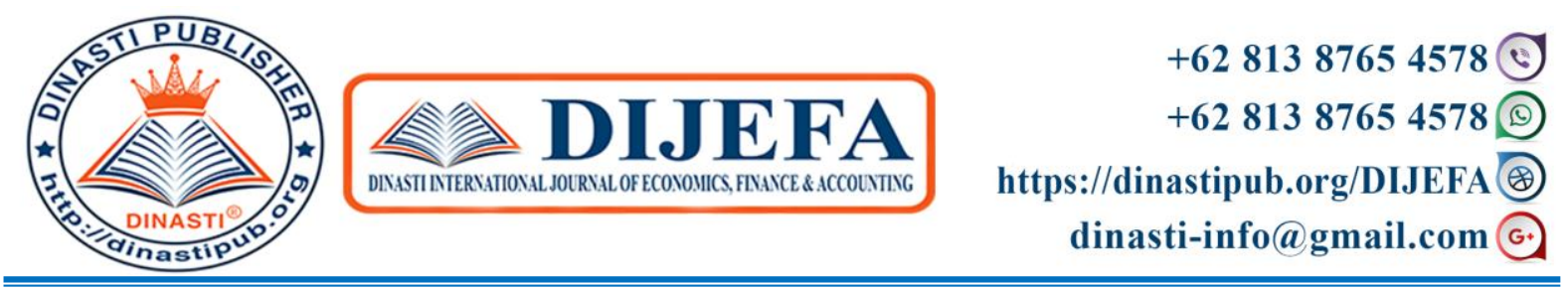

\title{
DETERMINANT OF GOVERNMENT BANK PERFORMANCE THROUGH NIM AS
} INTERVENING

\author{
Laynita Sari $^{1}$, Nandan Limakrisna ${ }^{2}$, Renil Septiano ${ }^{3}$ \\ 1) STIE KBP Padang \\ 2) Universitas Persada YAI, Indonesia \\ ${ }^{3)}$ STIE KBP Padang
}

ARTICLE INFORMATION

Received: 25 August 2020

Revised: 1 September 2020

Issued: 24 September 2020

Corresponding author: first author

E-mail:

laynitasari4@gmail.com

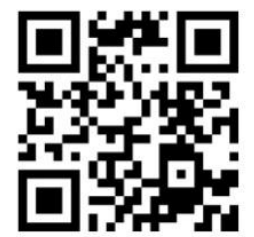

DOI: $10.38035 / D I J E F A$
Abstract: A government bank is a bank in which most of its shares are owned by the government. The government bank comprises four banks namely Bank Rakyat Indonesia, Bank Negara Indonesia, Bank Mandiri, and Bank Tabungan Negara. One ratio used to assess a bank's performance is the Return on Asset ratio. Each bank will try to keep its Return on Asset ratio consistently rising. But the phenomenon is that the Government Bank's Return on Asset ratio fluctuated from 2014 to 2019. I will therefore examine the factors that affect the ratio of Return on Assets to government banks. In this study, the ratio used was Non Performing Loan as independent variable, Net Interest Margin as intervening variable and Return on Asset on dependent variable. The result that the Net Interest Margin variable does not mediate the relationship between Non Performing Loan and Return on Asset.

Keywords: NPL, ROA, NIM, Government Bank

\section{INTRODUCTION}

A bank is an institution that helps the economic development of a country. If the development grows well, it will boost the economy from the public, and instead of the development of the bank is bad or crisis, then the state of the country's economy is in dissipation. The definition of bank according to Article 2 of Law No. 10 of 1998 in banking is a business entity that collects funds from the public in the form of deposits and distributes them to the public to improve the living standards of the people.

The financial development or performance of a bank from its profitability performance. According to Bank Indonesia, the important profitability ratio for banks is Return On Asset (ROA) (Latifah et al., 2012). According to (Astohar, 2016) Return On Asset 
(ROA) is used to measure bank profitability. This is also in line with the direction of Bank Indonesia as a banking supervisor and supervisor is under the auspices of the Financial Services Authority (OJK) prioritizing the profitability value of banks. The greater return on asset (ROA) can be said to be the higher the level of profit achieved by the bank, which is certainly the optimal position of the bank in terms of the use of assets.

In Indonesia there are four government banks namely Bank Rakyat Indonesia, Bank Negara Indonesia, Bank Mandiri, and Bank Tabungan Negara. This government bank is a state-owned bank because its shares are majority controlled by the government. Therefore, government banks are more trusted by the public to save and for loans. The government bank will also try to keep the ROA up.

Table 1 Financial Ratios of Gvernent Banks

\begin{tabular}{cccc}
\hline \multirow{2}{*}{ Year } & \multicolumn{3}{c}{ RASIO (\%) } \\
\cline { 2 - 4 } & ROA & NPL & NIM \\
\hline 2014 & 3,19 & 2,45 & 6,31 \\
2015 & 2,86 & 2,69 & 6,33 \\
2016 & 2,56 & 2,95 & 6,36 \\
2017 & 2,72 & 2,62 & 5,96 \\
2018 & 2,74 & 2,42 & 5,65 \\
2019 & 2,27 & 3,02 & 5,17 \\
\hline
\end{tabular}

Source: Financial Statements from each government bank

From the table above explains the changes in ROA, NPL, and NIM during the period 2014 to 2019. There is an inconsistent relationship between ROA variables and NPL and NIM variables. The desired ROA ratio always rises, but in fact from 2014 to 2019 the financial ratio of ROA of the Government Bank is volatile. The phenomenon that occurred from 2014 to 2016 is that the ROA ratio of government banks always decreased, where in $20143.19 \%$ decreased by $0.33 \%$ in 2015 , so the ratio of ROA in 2015 to $2.86 \%$. In 2016 the ROA ratio decreased again from $0.3 \%$ in 2015 to $2.56 \%$. In 2017 the ROA ratio increased by $0.16 \%$ from 2016 so the ROA ratio to $2.72 \%$, in 2018 the ROA ratio also increased by $0.02 \%$ from 2017 to $2.74 \%$. But in 2019 the ROA ratio decreased by $0.47 \%$ so that the ROA ratio increased by $2.27 \%$. During 2014 to 2019 , this was the largest decrease in ROA ratios.

No less important in maintaining the bank's performance to grow properly, one of the financial ratios of concern is the Non Performing Loan (NPL) ratio. Banks should keep this NPL ratio always down, because if it allows this ratio to increase it will impact the decline in profits, and eventually the bank's performance will fall. After observing the Government Bank's NPL ratio from 2014 to 2019, there is a phenomenon where from 2014 to 2016 the NPL ratio always increases, where in 2014 it increased by $2.45 \%$ by $0.23 \%$ in 2015 so the NPL ratio to $2.69 \%$. In 2016, the NPL ratio increased by $0.26 \%$ from 2015 to $2.95 \%$. In 2017 , the NPL ratio decreased by $0.33 \%$ from 2016 to $2.62 \%$. In 2018 the NPL ratio also decreased by $0.20 \%$ from 2017 to $2.42 \%$. But in 2019 the NPL ratio increased by $0.60 \%$ to $3.02 \%$. During 2014 to 2019 the largest increase in NPL ratio occurred in 2019.

In examining the ratio of ROA and NPL there is a research gap in previous research conducted by (Prihartini, Dana, 2018) where research was conducted at Bank Rakyat Indonesia, resulting in that the direct influence of NPL on ROA distribution is negative and 
significant. This means that the larger the non-performing loans, the more revenue reflected through the ROA will also be reduced. Meanwhile, research conducted by (Muliawati, Khoiruddin, 2015) which examined sharia banks resulted in a partial NPF positive effect on ROA showed by a regression coefficient of 0.571 and a significance rate of over 0.05 which is 0.571. Research on NPL and ROA ratios has also been conducted by (Sari, Tanno, Putri, 2019) where the ratio of NPL as a moderation variable results in that the NPL Variable is not a moderation between LDR and ROA, so it can be concluded that the NPL variable is not a moderating variable.

Besides the NPL and ROA ratios, the ratio that is no less important in banking is the Net Interest Magin ratio. Net Interest Margin is the ratio used to analyze how much net interest income compares to the company's productive assets. In table 1 above we can see that the ratio of NIM to government banks from 2014 to 2016 always rises, and from 2017 to 2019 the NIM ratio of government banks always falls. We can see that from 2014 to 2015 the NIM ratio increased by $0.02 \%$ to $6.33 \%$ in 2015 . In 2016, the NIM ratio also increased by $0.03 \%$ from 2015 to $6.36 \%$. In 2017 there was a decrease in NIM by $0.41 \%$ from 2016 to NIM in 2017 to $5.96 \%$. In 2018 NIM again decreased by $0.31 \%$ from 2017 so that in 2018 the NIM ratio to 5.65\%. During 2014 to 2019, the most NIM decrease occurred in 2019, where NIM decreased by $0.48 \%$ from 2018 to NIM in 2019 by $5.17 \%$.

Research by (Arsyad, 2019) which conducted research on banks found that NIM had a significant positive effect on profitability. While the results of the study by (Pedro and Yunanto, 2018) showed results that NIM had no significant positive effect on ROA. Other research conducted by (Harun, 2016) states that NIM has no effect on ROA.

From the phenomenon described above and there is a research gap in the previous research, this research issue concerning banking performance is proxy'd with ROA. This research aims to conduct empirical studies on the factors that influence changes in ROA that impact the banking performance of the Government Bank. Some previous studies have examined using the same variable, then several factors that will be tested affect the ROA, namely the calculation of NPL and NIM ratios as intervening variables in government banks.

\section{LITERATURE REVIEW}

\section{Bank}

The understanding of the Bank based on Law No. 10 of 1998 on banking that perfected Law No. 7 of 1992 on banking, is: "Bank is a business entity that raises funds from the community in the form of deposits and distributes it to the public in the form of credit and or other forms to improve the living standards of many people". So banks are business entities whose business activities raise funds from the community in the form of deposits and channel them back to the community in the form of credit and or in other forms and providing other bank services to improve the living standards of many people.

The Bank is a financial institution whose major activity is to raise funds from the community and re-channel the funds to the community and provide other Bank services (Kashmir, 2018).

\section{Government Bank}


It regulates the Government Bank in Law No. 19 of 2003 on BUMN (referred to as the BUMN Law). This law gives the understanding of so-called BUMNs themselves. In Article 1 number 1 of the BUMN Law states that BUMNs are business entities that all or most of the capital is owned by the state through direct participation derived from the wealth of a segregated country.

\section{Bank Financial Performance}

The performance of the company as a formal business carried out by the company to test the efficient and effectiveness of the company's activities that have been carried out in a certain period. Financial performance is the determination of certain measures that can measure the success of an organization or company in generating profit (Sucipto, 2003).

An assessment of a bank's performance can be done by analyzing financial statements. Financial statements comprising balance sheets will inform outside banks, such as the Central Bank, the public, and external parties can also use investors about the picture of its financial position to assess the amount of risk that exists in a bank. Other financial statements namely profit or loss summarize the development of the bank's business. The financial statements also show the Bank's performance.

\section{Return On Asset (ROA)}

In this study, banking performance was measured by ROA, where ROA measures the bank's management's ability to manage its assets for overall profit (Dendawijaya, 2003). The larger the ROA of a bank, the greater the level of profit achieved by the bank and the better it is an important indicator of the ratio for shareholders and potential investors to measure the Bank's ability to get net income associated with dividend payments.

According to SE BI No. 13/24/DPNP dated October 25, 2011, the ROA standard set for banks in Indonesia is at least $1.5 \%$. Then the formula for calculating Return On Asset (ROA):

ROA $=\frac{\text { Profit Before Tax }}{\text { Average Total Assets }} \times 100 \%$

\section{Non Performing Loan (NPL)}

Non Performing Loan (NPL) is a key indicator in assessing the bank's function performance, high NPL value can be said to be an overview of the bank's failure to manage the business causing liquidity problems (inability to pay third parties), Rentability (nonbillable debt), Solvency (Reduced capital). Meanwhile, falling profits are one consequence because practical banks lose sources of income besides having to set aside reserves according to credit collectibility.

According to SE BI No. 13/24/DPNP dated October 25, 2011 Credit risk is the risk because of the failure of the debtor and or any other party in fulfilling obligations to the bank. A healthy Non Performing Loan (NPL) standard of the non-performing loan amount is not over $5 \%$ of the total credit given to the debtor. If it exceeds $5 \%$, it will affect the bank's health level. Then the NPL formula: 
$N P L=\frac{\text { Non Performing Loans }}{\text { Total Credits Issued }} \times 100 \%$

The NPL describes the level of non-performing loans held by a bank. The higher the NPL will make net interest income fall, and the higher the NPL will be. Research supports this hypothesis (Brock, Suarez, 2000), (Rokhim and Wulandary, 2012) and (Syarif, 2006) that shows NPL has a negative relationship to NIM. Then researchers can lower the first hypothesis:

\section{H1 : NPL has a significant negative effect on NIM}

In previous research on the ratio of NPL and ROA conducted by (Prihartini, Dana, 2018) where research was conducted on Bank Rakyat Indonesia, resulted in that the direct influence of NPL on ROA distribution was negative and significant. This means that the larger the non-performing loans, the more revenue reflected through the ROA will also be reduced. Similar research was also conducted by (Zeuspita, Yadnya, 2019) research conducted on public banks on the Indonesia Stock Exchange, stating that NPL had a significant negative effect on ROA on commercial banks in idX for the period 2013-2015. The results the implication that bank management should have wonderful ability in credit assessment, assessment of guarantees and monitoring of debtors, thus allowing banks to avoid the buildup of bad loans that can later affect the bank's ROA on loan interest paid by debtors. Other research also conducted by (Peling, Sedana, 2018) at BPD Bali bank for the period 2009-2016 resulted in that NPL had a negative and significant effect on ROA in PT. Bank Pembangunan Daerah Bali period 2009-2016. This means that the higher the risk of credit, the lower the income received by BPD Bank. Then researchers can lower the second hypothesis:

\section{H2 : NPL has a significant negative effect on ROA Net Interest Margin (NIM)}

Net Interest Margin (NIM) is a comparison between net interest income to average productive assets. This ratio shows the ability of banks to generate net interest income with placing productive assets. The greater this ratio, the better the bank's performance in generating interest in income. However, it must be ensured that this is not because of high intermediation costs, assuming interest income should be replanted to strengthen the bank's capital (Taswan, 2010).

According to SE BI No. 13/24/DPNP dated October 25, 2011, the NIM standard stipulated for banks in Indonesia is at least 3\%. Then the formula for calculating the Net Interest Margin (NIM):

$$
N I M=\frac{\text { Net Interest Income }}{\text { Average Productive Assets }} \times 100 \%
$$

In previous research, on the ratio of Net Interest Margin to Return On Asset conducted by (Arsyad, 2019) conducted research of banks in Egypt found that NIM had a significant positive effect on profitability. Similar research conducted by (Sugiantari, Dana, 2019) found that Net Interest Margin had a positive and significant effect on ROA. Other 
research also conducted by (Grace, Yatna, 2019) on conventional public banks book four shows Net Interest Margin (NIM) has a positive and significant effect on profitability proxies by Return On Asset at Conventional Commercial Bank BUKU 4. Then the researchers can lower the third hypothesis and the fourth:

\section{H3 : NIM has a significant positive effect on ROA}

H4 : NIM has a positive and significant influence as mediation between NPL and ROA

\section{RESEARCH METHODS}

\section{Research Sites}

This research at the Government Bank through financial report data for the period 2014-2019. Through financial statements owned by the Government Bank, researchers processed the data according to the variables used in the study, both for independent variables, mediation variables, and dependent variables. Thus the data processed by the researchers is quantitative data. It gets the financial statements used from each official website of BANK BRI, Bank BNI, Bank Mandiri, and Bank BTN.

Quantitative research includes relatively extensive libraries to give direction to research questions or hypotheses. In planning quantitative research, library studies are often used to usher in a problem in the introduction, (Ali \& Limakrisna, 2013).

\section{Research Design}

This research wants to find out how independent variables such as Non Performing Loan (NPL) affect dependent variables, namely Return on Assets (ROA) of Government Banks through Net Interest Margin (NIM) as intervening variables. This research used data in the form of semester financial statements owned by the Government Bank in the period 20142019. We get this financial report data from each official website of BANK BRI, Bank BNI, Bank Mandiri, and Bank BTN.

\section{Data Collection Methods}

The method of collecting data in this study is to collect data from the semester financial statements of the Government Bank from the period 2014 to 2019. We get this financial report data from each official website of BANK BRI, Bank BNI, Bank Mandiri, and Bank BTN.

\section{Types and Data Sources}

The data used in this study is secondary data is already in the form of reports, already recorded and can be trusted the truth. While the data source in this study comes from the official website of the Government Bank in the form of semester financial statements belonging to Bank BRI, Bank BNI, Bank Mandiri and Bank BTN from 2014 to 2019.

\section{Data Analysis}

Based on the conceptual framework that has been created, the data analysis used in this study is path analysis. It uses path analysis when independent variables can directly or indirectly affect dependent variables. Indirect effect here means that there are intervening variables that mediate the influence of independent variables on dependent variables.

Path analysis is a multivariate data analysis method to know the direct and indirect influence of multiple causal variables (exogenous) on endogenous variables (consequences) 
with recursive patterns, and all variables can be observed directly. Recursive means that the relationship between variables is one-way, there is no reciprocal relationship. If stated A cause B, then B cannot cause A, (Ali \& Limakrisna, 2013).

\section{FINDINGS AND DISCUSSION}

The results of the model 1 hypothesis test on the influence of NPL on motivation in table 2 below:

Table 2 Effect of NPL on NIM

\begin{tabular}{|c|c|c|c|c|c|c|}
\hline \multirow[b]{2}{*}{ Model } & & \multicolumn{2}{|c|}{$\begin{array}{l}\text { Unstandardized } \\
\text { Coefficients }\end{array}$} & \multicolumn{3}{|c|}{ Standardized Coefficients } \\
\hline & & B & Std. Error & Beta & $\mathbf{t}$ & Sig. \\
\hline \multirow[t]{2}{*}{1} & (Constant) & 8.353 & .632 & & 13.216 & .000 \\
\hline & NPL & -.865 & .224 & -.498 & -3.854 & .000 \\
\hline
\end{tabular}

a. Dependent Variable: NIM

Formulate SPSS test results regression equations:

$\mathrm{NIM}=8,353-0,865 \mathrm{NPL}$

The hypothetical test results of model 2 influence of NPL, NIM on ROA in table 3 below:

Table 3 Effect of NPL, NIM on ROA

\begin{tabular}{|c|c|c|c|c|c|c|}
\hline & \multirow[t]{2}{*}{ Model } & \multicolumn{2}{|c|}{$\begin{array}{l}\text { Unstandardized } \\
\text { Coefficients }\end{array}$} & \multicolumn{3}{|c|}{ Standardized Coefficients } \\
\hline & & B & Std. Error & Beta & $\mathbf{t}$ & Sig. \\
\hline \multirow[t]{3}{*}{1} & (Constant) & 1.258 & .502 & & 2.508 & .016 \\
\hline & NPL & -.499 & .093 & -.394 & -5.369 & .000 \\
\hline & NIM & .471 & .054 & .644 & 8.788 & .000 \\
\hline
\end{tabular}

a. Dependent Variable: ROA

Formulate SPSS test results regression equations:

ROA $=1,258-0,499 \mathrm{NPL}+0,471 \mathrm{NIM}$

Analyze the test results of each variable independent of its dependent variables:

1. NPL to NIM

H1 : NPL has a significant negative effect on NIM

The results of the NPL influence test on NIM a $t$ value of $-3,845$ significance of 0.000 . A value of significance smaller than 0.05 shows that NPL has a significant negative effect on NIM. This means it accepts Hypothesis 1.

\section{NPL to NIM}

H1 : NPL has a significant negative effect on NIM

The results of the NPL influence test on NIM a t value of $-3,845$ significance of 0.000. A value of significance smaller than 0.05 shows that NPL has a significant negative effect on NIM. This means it accepts Hypothesis 1.

\section{NIM to ROA}

H3 : NIM has a significant positive effect on ROA 
The results of the ROA-based NIM influence test were obtained a t value of 8,788 significance of 0.000 . A value of significance smaller than 0.05 shows that NIM has a significant positive effect on the ROA. This means it accepts Hypothesis 3.

Intervening Test Results for hypothesis 4, first determine the value of the determinant coefficient $\left(\mathrm{R}^{2}\right)$.

$\mathrm{R}$ square value of the regression in the following table:

Table 4 R Square NPL values

\begin{tabular}{ccccc}
\hline Model & $\mathbf{R}$ & R Square & $\begin{array}{c}\text { Adjusted } \\
\text { R Square }\end{array}$ & $\begin{array}{c}\text { Std. Error of the } \\
\text { Estimate }\end{array}$ \\
\hline 1 & $.498 \mathrm{a}$ & .248 & .231 & 1.15263 \\
\hline
\end{tabular}

a. Predictors: (Constant), NPL

In table 4 above we can see that the value of $\mathrm{R}$ square is 0.248 , this means that $24.8 \%$ of NIM is affected by NPL, other variables affect the remaining $75.2 \%$.

$$
\mathrm{e} 1=\sqrt{ }(1-0,248)=0,867
$$

Tabel 5. R Square NPL, NIM values

\begin{tabular}{ccccc}
\hline Model & $\mathbf{R}$ & R Square & $\begin{array}{c}\text { Adjusted } \\
\text { R Square }\end{array}$ & $\begin{array}{c}\text { Std. Error of the } \\
\text { Estimate }\end{array}$ \\
\hline 1 & $.907 a$ & .822 & .814 & .41416 \\
\hline
\end{tabular}

a. Predictors: (Constant), NIM, NPL

In table 5 above we can see that the $\mathrm{R}$ square value is 0.822 , this means that $88.2 \%$ of ROA is affected by NPL and NIM, other variables affect the remaining $17.8 \%$.

$\mathrm{e} 2=\sqrt{ }(1-0,822)=0,422$

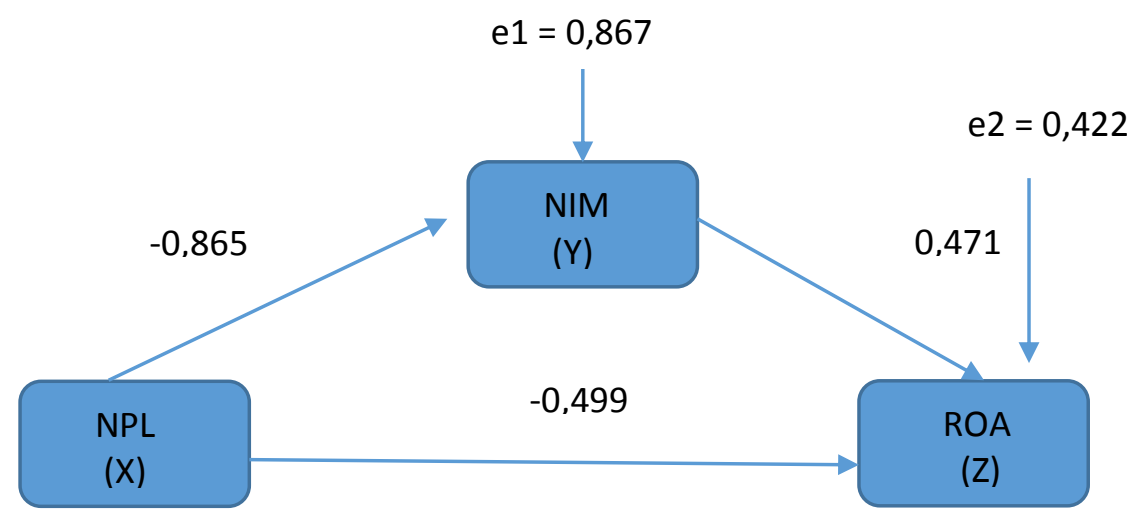

\section{NPL to ROA mediation NIM}

H4 : NIM a positive and significant influence as mediation between NPL and ROA How the NPL affects the ROA mediated by NIM, first do the following calculations:

$\mathrm{X} \rightarrow \mathrm{Z}=-0,499$

$X$ through $Y$ to $Z=-0,865 \times 0,471=-0,407$

Total influence exerted $X \quad Z=-0,499-0,407=-0,906$ From the calculation above, we can know that the direct influence $>$ indirect influence, where $-0.499>-0.906$. This means that 
NIM does not exert influence between NPL and ROA on government banks. It rejects hypothesis 4.

\section{CONCLUSION AND SUGESTION CONCLUSION}

Based on the test results and discussion of hypotheses described earlier, we can draw it to some conclusions:

1. Non Performing Loans on Government Banks has a negative and significant influence on Net Interest Margin. We can see this from the data processing result where the $t$ value is $-3,845$ significance of 0.000 . This means that if the amount of bad loans at the Government Bank is high, then the net interest income at the Government Bank will fall.

2. 2. Non Performing Loans at Government Banks has a negative and significant influence on Return On Assets. We can see this from the data processing result where the $t$ value of $-5,369$ significance is 0.000 . This can mean that if the amount of bad credit at the Government Bank is high, then the profit will fall.

3. 3. Net Interest Margin on Government Bank has a positive and significant influence on Return On Asset. We can see this from the data processing results where the $\mathrm{t}$ value of 8,788 significance is 0.000 . This can mean that if the net interest income at the Government Bank is high, then the profit will also rise.

4. 4. Net Interest Margin on Government Banks does not affect non-performing loans and return on assets. We can see this from the results of the calculation and the comparison between direct and indirect influence. The direct influence is between NPL on ROA and indirect influence that is NPL on ROA through NIM. Got the result that the direct influence $>$ of indirect influence were $-0.499>-0.906$. This can mean that the net interest income at the Government Bank has no effect on bad loans and profits.

5.

\section{SUGGESTION}

1. The Government Bank to keep its NPL ratio consistently down, because if this NPL grows it will reduce the company's profit, and affect the company's performance.

2. The Government Bank to increase its ROA ratio and be able to maintain consistently so that the ratio always rises.

3. NIM ratio is also a positive influence to ROA, so that government banks can optimize this ratio to continue to grow by not ruling out the principle of prudence.

\section{REFERENCE}

Ali, H., \& Limakrisna, N. (2013). Research Methodology, Practical Guide to Solving Business Problems. In: Preparation of Theses and Dissertations.

Ali, H., \& Limakrisna, N. (2013). Metodologi Penelitian (Petunjuk Praktis untuk Pemecahan Masalah Bisnis, Penyusunan Skripsi, Tesis, dan Disertasi). 
Anugrah, T., \& Yatna,. (2020). Pengaruh Non Performing Loan, Loan To Deposit Ratio, Net Interest Margin, Biaya Operasional Pendapatan Operasional Dan Capital Adequacy Ratio Terhadap Profitabilitas Bank Umum Konvensional Buku 4 Periode 2012-2016. 4(1).

Brock, P. L., \& Suarez, L. R. J. J. o. d. E. (2000). Understanding the behavior of bank spreads in Latin America. 63(1), 113-134.

Dendawijaya, (2003). Manajemen Perbankan Cetakan Kedua.

Harun, (2016). Pengaruh Ratio-ratio Keuangan Car, Ldr, Nim, Bopo, Npl Terhadap Roa. 4(1), 67-82.

Indonesia. (1992). Undang-Undang nomor 7, tahun 1992 tentang perbankan: Mini Jaya Abadi.

Kasmir, S. (2018). Bank dan Lembaga Keuangan Lainnya Edisi Revisi.

Latifah, N. M., Rodhiyah, R., \& Saryadi, S. (2012). Pengaruh Capital Adequacy Ratio (CAR), Non Performing Loan (Npl) Dan Loan to Deposit Ratio (Ldr) Terhadap Return on Asset (ROA)(Studi Kasus Pada Bank Umum Swasta Nasional Devisa Go Public Di Bursa Efek Indonesia Periode 2009-2010). 1(2), 57-66.

Muliawati, S. (2015). Faktor-faktor penentu profitabilitas bank syariah di Indonesia. Universitas Negeri Semarang,

No, S. E. B. I. 13/24/DPNP tanggal 25 Oktober 2011.

No, U.-u. tahun 2003 tentang Badan Usaha Milik Negara (BUMN).

Nomor, U.-U. tahun 1998 tentang Perbankan. In: Jakarta: Harvarindo.

Peling, I. A. A., \& Sedana, (2018). Pengaruh LDR, NPL, dan BOPO terhadap profitabilitas pada PT. BPD Bali periode tahun 2009-2016. 7(6).

Prihartini, S., \& Dana, (2018). Pengaruh Car, Npl, dan Roa terhadap Penyaluran Kredit USAha Rakyat (Studi Kasus pada PT Bank Rakyat Indonesia Tbk). 7(3).

Sari, L., Tanno, A., \& Putri, (2020). Peran NPL Terhadap Hubungan Antara LDR dan Kinerja Perusahaan (Study Empiris Pada Bank BUMN yang Terdaftar di BEI). 3(2), 45-56.

Sucipto,. (2003). Penilaian Kinerja Keuangan.

Syarif, S. (2006). Analisis Pengaruh Rasio-Rasio Camels Terhadap Net Interest Margin (Study Empiris Pada Bank-bank yang Listed di Bursa Efek Jakarta Periode Tahun 2001-2004). program Pascasarjana Universitas Diponegoro,

Taswan, C., \& Si, (2010). Manajemen Perbankan.

www.bni.co.id.

www.bri.co.id

www.mandiri.co.id

www.btn.co.id 